Research Fellow of the Institute. It will be published three times a year, once in each academic term. The first number includes reports on the Ashanti Research Project (see Africa, April I 965, p. 21 I); the Volta Basin Survey (an emergency scheme for the recording of basic ethnographic and historical data from the towns and villages to be inundated); the collection of Arabic manuscripts, initiated in $196 \mathrm{r}$; and language research by the Summer Institute of Linguistics (field studies, training courses in descriptive linguistics, and linguistic workshops). Individual research reports include fieldwork at Banda and Wenchi, August 1964, by Paul Ozanne; visits to archives in Lisbon and Paris, by G. S. P. FreemanGrenville, and a note on Ahago oral tradition, by K. Arhin. The Institute intends to establish a small museum for teaching purposes and has set up a temporary exhibition of various objects in its possession.

\title{
Oxford University Africa Society
}

Oxford University Africa Society is extending its activities to meet the increasing interest being shown in Africa. It was founded in 1958 with the aim of encouraging interest in and discussion of African affairs and to provide a platform for the presentation of African opinion; it also fosters friendly relations by means of social gatherings and arranges film shows, exhibitions, and other cultural activities. The Society now has an annual membership of about 200, one third being African nationals.

\section{The African Bibliographic Center, Washington}

ThE African Bibliographic Center (P.O. Box 13096 , Washington 20009, D.C.) is increasing the scope and coverage of its bi-monthly publication, $A$ Current Bibliography on African Affairs, by including a review and forthcoming publications section in addition to the usual general and geographic sections.

\section{Recordings of African Music from $\mathrm{OCORA}$}

'VAlima-Madagascar' (OCR $x$ ) is a recent recording from OCORA (Office de Coopération Radiophonique, 46, rue d'Amsterdam, Paris $\left.9^{\mathrm{e}}\right)$. It features the valiha, the wellknown stringed instrument of Madagascar, and includes an illustrated booklet describing the richness and variety of the valiha repertoire. The recordings were made in August 1963 by M. Charles Duvelle, with the collaboration of M. Michel Razakandraina of the Radiodiffusion Nationale Malgache. Other OCORA recordings listed in their catalogue include music of the Bamum, Fali, Baoule, Dogon, Kabre, and the Griots of Senegal, as well as recordings from Dahomey, Gabon, the Central African Republic, Haute-Volta, and Niger.

\section{Publications of the Museum of Primitive Art, Nen York}

THE Museum of Primitive Art, New York, has produced a number of books on African art, including studies of Senoufo and Bambara sculpture, by Robert Goldwater, Sculpture of Northern Nigeria, by Roy Sieber, and The Latest Ife Finds, with a note by William Fagg. A bibliography of Yoruba sculpture is forthcoming. A full list of the Museum's publications may be obtained from the distributors: New York Graphic Society, Publishers, Ltd., Dept. MP, Greenwich, Connecticut.

\section{Second Editions and Reprints}

The second edition of The Missionary Factor in East Africa, by Roland Oliver (London: Longmans, 1965, 125. 6d.) has a new foreword by the author and some corrections have been made. It was first published in 1952. 
Mary Kingsley's Travels in West Africa, first published in 1897, has now appeared in a third edition (London: Frank Cass, 1965, 705.) with a new introduction by John E. Flint.

The Story of the Rhodesias and Nyasaland, by A. J. Hanna (London: Faber, I965, 30s.) has been revised for the second edition and brought up to date to the dissolution of the Federation.

Sylvia Leith-Ross's African Women: a Study of the Ibo of Nigeria (London: Routledge and Kegan Paul, 1965, 425.) was first published in 1939.

Catalogue of African Dictionaries, Grammars and Phrase-books

A NEw edition of the Oriental-African Catalogue of Dictionaries, Grammars and Phrase-books, including the Languages of the Americas, first published in 1956, has recently appeared from Bailey Bros. and Swinfen, London. It covers more than 250 languages, listed alphabetically, of which over roo are African languages.

\section{Church Missionary Society: Temporary Closing of Archives}

THE Church Missionary Society (6 Salisbury Square, London, E.C. 4) is moving its headquarters to Waterloo in 1966 , and the archives office is now closed to students. It is proposed to reopen the office in October 1966 , when students will be welcome to make use of the improved facilities available. 